\title{
Is the long recession at an end?
}

\section{After nearly a decade of deepening recession, it is natural to hope that rising stock markets mean the end is near. But it is too soon to cheer. Too many structural weaknesses persist.}

Hurrah, the long recession is coming to an end. That is the simplest interpretation of what has happened in the past few weeks on the international stock markets, Wall Street in particular. For if people are willing once again enthusiastically to invest in the shares of industrial corporations instead of lending to their governments, does that not imply that confidence in the future is flowing back? That the corporations whose shares are being snapped up will now adjust their research and development plans to encompass projects not directed at short-term goals? That the same corporations will return to the labour market for scientists and engineers? And that the rising tide of prosperity that the ending of the recession could bring may permit and even encourage governments to relax the parismonious strings by which basic research and university research in particular have for too long been constrained? Hopeful speculation along these lines is inevitable but, unfortunately, also premature.

Prudent scepticism springs from several sources. What has happened in the past few weeks on Wall Street has happened before. The flurry of excitement about the stocks of industrial corporations in August this year, in retrospect the first step in the upward movement of stock prices that has now carried the Dow Jones index of industrial stocks to more than 1000 , was quickly followed by a trend in the opposite direction. The same could happen now, but probably not precipitously; eagerness to buy shares in industrial corporations has spread beyond the financial institutions to ordinary people wondering what to do with their savings, thus generating momentum that will not quickly be dissipated. But last week's peak on Wall Street is not in any case the Everest that it seems. The index had not then managed to exceed the value of 1051 that it reached in 1973, on the eve of the first dramatic increase of the international price of oil. That is a measure of how far the value of industrial enterprises has been depressed by the long recession. Yet now, it seems, potential investors are declaring with their pocket-books that they believe that prosperity is round the corner. Will they be proved right?

The signals are contradictory. The biggest plus is the decline of the inflation rate in the United States, from close on 15 per cent three years ago to an estimated 4-5 per cent by the end of this year. This is striking proof of the flexibility of the US economy, and that the monetarist monetary policies followed by the Federal Reserve Board in the past two years have been effective. Elsewhere, similar policies have worked less quickly. In Britain, three years of the Thatcher government's version of monetarism preceded by at least a year of Labour government's restraint have produced a less dramatic reduction of inflation (which may nevertheless turn out to be only 6 per cent by the end of this year). No wonder, in the circumstances, that the dollar remains for the time being strong. The minuses, unfortunately, are also memorable. The chief of these is that in the United States the federal government is still with its eyes open running a budget deficit of more than $\$ 100,000$ million, the consequences of which are more than ever likely to be inflationary now that the Federal Reserve Board has decided (last week) to encourage a downward trend of interest rates. For to the extent that people with money to invest (savings, in other words) are now less likely to be attracted by lending to the government (which may partially account for the high jinks on Wall Street), the Department of the Treasury may have to resort to the printing press to keep the government in business. That could quickly crimp Wall Street's enthusiasm.

Three more deeply seated worries cry out. First, throughout the industrial world except (for special reasons) Japan, unemployment has risen to heights unprecedented for half a century. In the United States, unemployment amounts to more than 10 per cent of the potential workforce. In Britain, the magic figure of 3 million unemployed has long since been passed, but the dole queues are still lengthening. Even once ebullient countries such as West Germany are learning to live with unemployment (while France is following the 1960s practice of trying to make the problem go away by public spending sustained by external devaluation and borrowing from the international banks). The trouble is that much present unemployment will persist (and be a public charge) unless governments are much cleverer than in the past at fitting badly trained or untrained people for the world that lies ahead. Second, and closely linked, is the glaring truth that even the hardships of the past few years have not made industrial and service enterprises in the West into the super-productive outfits they could be. British motor car manufacturers, for example, still compete poorly with those elsewhere except in their wage rates (which is hardly a cause for boasting). This points to one respect in which the recession as so far run is incomplete, and the third shadow over the next few months: many of the corporations whose shares have been bought in the past few days are so dependent on bank loans that they may never be able to repay, and in the circumstances (such as low wage rates) peculiar to the middle of a recession, they may not be able to survive the glare of whatever light there may be at the end of the tunnel. The international banks, with their mountain of doubtful debts still counted as assets in their balance sheets, are very vulnerable.

For the time being, none of this seems to weigh with those with money to invest. The Federal Reserve Board may have made lending to the government unfashionable, but there is no reason to suppose that the huge flow of cash down Wall Street will immediately be converted into radical innovations that will sustain some future era of prosperity. Although investors seem marvellously to have been persuaded that manu facturing industry has a future, manufacturers themselves are noticeably more cautious. The explanation is not hard to find. In the usual economic cycle of boom, bust, recession and recovery, fortunes are made in the first two cycles and stand to be lost (as stands to reason) in the second two. The trouble, this time round, is that the structural problems of industry (public as well as private) persist. There has been an ample harvest of bankruptcies (which will continue) but nothing yet to suggest that some brave new world is about to be inhabited. Governments for the past few years preoccupied with the passive enforcement of monetary restraint must now take a more emphatic view. Briefly, in the interests of their own survival (and of the well-being of those who vote them into office) they must put their money where their mouths are, and must invest in the only window on the future they are allowed by their constitutions to occupy - the exploration of what the future is like, and how to live with it. But that means research and education, surely? Surely. So governments in Washington and elsewhere should give up trying to second-guess Wall Street, which is itself a symptom and not a cause, and themselves intelligently begin investing in the intangible commodities that may help to ensure that there is a future for all of us. 